\title{
Isolation of Trichoderma harzianum and Evaluation of Antagonistic Potential against Alternaria alternata
}

\author{
K.V.M.S. Chaitanya, Harison Masih and Pakkala Abhiram* \\ Department of Industrial Microbiology, Jacob Institute of Biotechnology and Bioengineering, \\ SHUATS, India \\ *Corresponding author
}

\begin{tabular}{|l|}
\hline K e y w o r d s \\
$\begin{array}{l}\text { Trichoderma harzianum, } \\
\text { Alternaria alternate, } \\
\text { Inhibition, Dual culture } \\
\text { plate technique }\end{array}$ \\
\hline Article Info \\
\hline $\begin{array}{l}\text { Accepted: } \\
\text { 20 September } 2018 \\
\text { Available Online: } \\
\text { 10 October } 2018\end{array}$ \\
\hline
\end{tabular}

\section{A B S T R A C T}

Chilli is one of the important spices and cultivated around the world for its peculiar hot taste. Chilli leafs prone to affect by Alternaria alternata (leaf spot). In order to overcome this problem, efforts have been made to evaluate the efficiency of the bio-control agent Trichoderma harzianum for controlling the leaf spot disease in chilli. Trichoderma harzianum was isolated from the field soil and identified through microscopic and recommended standard methods. The antagonistic activity of the Trichoderma harzianum was evaluated against the pathogenic fungi responsible for leaf spot disease. Alternaria alternata belongs to the sub-division Deuteromycotina, class Dothideomycetes, family Pleosporaceae. The mycelium of Alternari alternata is septate, brown to brownish grey in colour. The conidiophores are dark, septate, arise in fascicles, measuring 14-74 $\times 4-8 \mu \mathrm{m}$. Conidia are brownish black, obclavate, borne singly or sparingly in chains of $2-4$, muriform with long beak and the overall conidial size ranges between 148-184 $\times 17-24 \mu \mathrm{m}$ with 10-11 transverse and Alternaria alternata proved the efficiency to inhibit. The antagonistic activity of Trichoderma harzianum was screened in vitro against Alternaria alternata by dual culture plate technique on PDA media for 7 days. The results revealed Trichoderma harzianum was shown inhibition of $60.71 \%$ over Alternaria alternata.

\section{Introduction}

Chilli is one of the important spices and cultivated around the world for its peculiar hot taste. Chilli leafs prone to affect by Alternaria alternata (leaf spot). In order to overcome this problem, efforts have been made to evaluate the efficiency of the bio-control agent Trichoderma harzianum for controlling the leaf spot disease in chilli. Trichoderma harzianum was isolated from the field soil and identified through microscopic and recommended standard methods. The antagonistic activity of the Trichoderm aharzianum was evaluated against the pathogenic fungi responsible for leaf spot disease i.e., Alternaria alternaria belongs to the sub-division Deuteromycotina, class Dothideomycetes, family Pleosporaceae. Species of the genus are cosmopolitan, surviving both as saprophytes as well as weak parasites. The genus is characterized by the formation of polymorphous conidia either singly or in short or longer chains and provided with cross, longitudinal as well as oblique septa and having longer or short beaks 
(Nayyar et al., 2014). Yellow-brown spots with target-like concentric rings appear on leaves, as well as dark brown sunken spots on heads of Brussels sprouts, broccoli, and cauliflower, chilli. These spots contain many spores which are spread by wind, rain, or on equipment and people. Spores require at least $9 \mathrm{hrs}$. of moisture to germinate and infect the plant. Older, senescing plant parts are more susceptible to infection (Wukasch et al., 1985).

The mycelium of Alternari alternata is septate, brown to brownish grey in colour. The conidiophores are dark, septate, arise in fascicles, measuring 14-74 × 4-8 $\mu \mathrm{m}$. Conidia are brownish black, obclavate, borne singly or sparingly in chains of 2-4, muriform with long beak and the overall conidial size ranges between 148-184 × 17-24 $\mu \mathrm{m}$ with 10-11 transverse and Alternaria alternata proved the efficiency to inhibit (Subash et al., 2014).

The use of various herbal extracts and natural products is being encouraged because these cause no health hazard or pollution. The extracts of Canna indica, Convolvulus arvensis, Ipomoea palmata, Cenchrus catharticus, Mentha piperita, Prosopsis spicigera, Allium cepa, Allium sativum, Lawsonia inermis, Argemone mexicana, Datura stramonium and Cleroden droninerme completely inhibited the spore germination of Alternaria brassicae, Alternaria altenata was isolated from leaves of cauliflower and chilli (Sheikh and Agnihotri, 1972).

The maximum residue limit (MRL) applied by legislation and buyers in the food industry is also increasingly strict, there is the risk of plant pathogens developing resistance to chemical control products. Biological control is therefore a useful and necessary part of growers' crop protection programmers. Biological control is based upon the natural enemies of harmful organisms, usually bacteria or fungi. These natural enemies are multiplied by manufacturers and sold as ready to- use control products. Growers can use biological control to replace (part of) their chemical control.

Several fungicides and botanicals belonging to various groups are recommended for the management of Alternaria leaf spot of chilli. Now-a-days farmers are using only the chemical fungicides for managing the disease, but it has the negative impact on the environment and develops resistant in pathogen. So due to these reasons use of specific chemical fungicides with recommended dosages bio-agent will not harm the environment and also will be effective in controlling the disease. So the studies are conducted to know the efficiency of fungicides, bio-agent in managing the Alternaria leaf spot of chilli caused by the Alternaria alternata.

\section{Materials and Methods}

\section{Isolation of Trichoderma harzianum from Agriculture soil}

The soil was collected from the Agriculture field and serially diluted till $10^{-5}$ dilutions separately and transfer $0.1 \mathrm{ml}$ of each dilution was placed on PDA media separately using spread plate technique. The plates were incubated at $25^{\circ} \mathrm{C}$ for 4 to 5 days and then analysis of morphological study (Aneja et al., 2003) was carried out.

\section{Lacto Phenol Cotton Blue staining of Trichoderma harzianum}

The lacto phenol cotton blue (LPCB) wet mount preparation is the most widely used method of staining and observing fungi. The preparation has three components, phenol, which was killed any live organisms, lactic acid which preserves fungal structures, and 
cotton blue which stains the chitin in the fungal cell walls. Place a drop of $70 \%$ alcohol on a separate microscope slides and immerse the fungal specimens in the drop of alcohol and add one or two drops of the lacto phenol /cotton blue stain before the alcohol dries out. Holding the cover slip between forefinger and thumb, touch one edge of the drop of mountant with the cover slip edge, and lower gently, avoiding air bubbles and observe under microscope (Aneja et al., 2003).

\section{Characterization of Trichoderma harzianum}

The thallus typically consists of a highly branched network of multi-nucleate. Manybranched conidiophores sprout on the mycelia. The conidiophores are the main dispersal route of the fungi, and often are green in color identified as Trichoderma harzianum.

\section{Biochemical tests}

\section{Amylase production test}

The isolate strains were inoculated into starch agar plates. All the inoculated as well as uninoculated (control) plates were incubated at $25^{\circ} \mathrm{C}$ for 7 days. After incubation period, surface of the plates with iodine solution with a dropper for 30 seconds and pour off the excess iodine solution. A typical positive starch hydrolysis reaction (i.e., clear zone surrounding the microbial colonies) shown by the Trichoderma harzianum (Azevedo et al., 2000).

\section{Cellulase production test}

The isolate strains were inoculated into Czapek-mineral salt medium plates. All the inoculated as well as un-inoculate (control) plates were incubated at $25^{\circ} \mathrm{C}$ for 7 days. After incubation period, surface of the plates with Hexadecyltrimethyl ammonium bromide (1\% solution) with a dropper for 30 seconds and pour off the excess Hexadecyltrimethyl ammonium bromide solution. A typical positive cellulase production test (i.e., clear zone surrounding the microbial colonies) shown by the Trichoderma harzianum (Gajera and Vakharia 2012).

Isolation and identification of Alternaria alternata

\section{Sample collection}

Soil samples from the chilli rhizosphere infested with Alternaria alternata was collected from 3 places of the field and mix well to make fine particles. Collection of soil samples were taken from the root zone at 5-15 cm depth.

\section{Morphological characteristics of Alternaria alternata}

The mycelium of Alternaria alternata is septate, brown to brownish grey in colour. The conidiophores are dark, septate, arise in fascicles. Conidia are brownish black, obclavate, borne singly or sparingly in chains with long beak.

This species represent slow and rudimentary growth in media and forms chlamydospores in less frequency (Kolte, 1985).

Antagonistic activity of Trichoderma harzianum against Alternaria alternata under in-vitro

Trichoderma harzianum was evaluated for its antagonistic activity against the Alternaria alternata. In Petri dishes containing PDA medium, inoculate Trichoderma harzianum and Alternaria alternata at $28^{\circ} \mathrm{c}$ for 7 days. Trichoderma harzianum was inhibiting the growth of the pathogen. The bio-control agent, Trichoderma harzianum colonize over the pathogen (Kumar et al., 2011). 


\begin{abstract}
Inhibition growth percentage $(\%)=$ conidiophores are the main dispersal route of $\mathbb{R 1 - R 2}$ the fungi, and often are green in colour

F1 X100

Where, identified. The biochemical tests (Amylase Production test, Cellulose Production test) used to identify the Trichoderma harzianum.
\end{abstract}

$\mathrm{R}_{1}=$ Growth of Trichoderma harzianum in petridish (mm).

$\mathrm{R}_{2}=$ Growth of Alternaria alternata in petridish (mm).

\section{Results and Discussion}

Isolation and biochemical tests of Trichoderma harzianum

In the present study Trichoderma harzianum was isolated by serial dilution method from the soil sample collected from the Agricultural field of SHIATS, Allahabad. In PDA medium individual colonies of filamentous fungi were picked up and purified by streaking on Agar medium and incubate at $25^{\circ} \mathrm{C}$ at 5-7 days. The fungal isolates were identified on the basis of macroscopic analysis in PDA medium. The fungal cultures were all incubated followed the recommendations of Pitt et al., (1979). The fungal isolates have on PDA the

\section{Biochemical tests}

Isolation and morphological characteristics of Alternaria alternata

Soil samples from the chilli rhizosphere infested with Alternaria alternata was collected from 3 places of the field and mixed well to make fine particles. Collection of soil samples was taken from the root zone at 5-15 $\mathrm{cm}$ depth. The mycelium of Alternaria alternata is septate, brown to brownish grey in colour. The conidiophores are dark, septate, arise in fascicles, measuring 14-74 × 4-8 $\mu \mathrm{m}$.

Conidia are brownish black, obclavate, borne singly or sparingly in chains of 2-4, muriform with long beak and the overall conidial size ranges between 148-184 × 17-24 $\mu \mathrm{m}$ with 10 11 transverse and 0-6 longitudinal septa. This species represent slow and rudimentary growth in media and forms chlamydospores in less frequency.

\title{
Table.1 Cultural characteristics of Trichoderma harzianum
}

\begin{tabular}{l|l|l|l|l|}
\multicolumn{1}{c|}{ Organism } & \multicolumn{2}{|c|}{ Media } & \multicolumn{3}{c}{ Cultural characteristics } \\
\hline $\begin{array}{l}\text { Trichoderma } \\
\text { harzianum }\end{array}$ & PDA & $\begin{array}{l}\text { Color } \\
\text { Texture } \\
\text { lower side cream }\end{array}$ & floccose & $\begin{array}{l}\text { Vegetative aerial hyphehyline or } \\
\text { trichotomously branched }\end{array}$ \\
\hline
\end{tabular}

Table.2 Morphological characteristics of Trichoderma harzianum

\begin{tabular}{|c|c|c|c|c|c|}
\hline \multirow[t]{3}{*}{ Organism } & \multicolumn{5}{|c|}{ Morphological characteristics } \\
\hline & \multicolumn{5}{|c|}{ Spore } \\
\hline & Type & Size & Shape & Septation & Arrangement \\
\hline $\begin{array}{l}\text { Trichoderma } \\
\text { harzianum }\end{array}$ & Conidia & $\begin{array}{l}\text { Conidiophore } 52-120 \mu \times 7 .- \\
11.5 \mu \text {,conidial head } 26.5- \\
28 \mu \text {,spore } 3-6 \mu\end{array}$ & $\begin{array}{l}\text { Spores are } \\
\text { spherical or } \\
\text { oval }\end{array}$ & Septate & $\begin{array}{l}\text { Spores } \\
\text { scattered or } \\
\text { clusters }\end{array}$ \\
\hline
\end{tabular}


Table.3 Biochemical test of Trichoderma harzianum

\begin{tabular}{|c|c|c|}
\hline Biochemical identification & Positive & Negative \\
\hline Amylase production test & $\sqrt{ }$ & $\times$ \\
\hline Cellulase production test & $\sqrt{ }$ & $\times$ \\
\hline
\end{tabular}

Table.4 Cultural characteristics of Alternaria alternate

\begin{tabular}{|l|l|l|l|l|}
\hline \multicolumn{1}{|c|}{ Organisms } & \multicolumn{2}{|c|}{ Media } & \multicolumn{3}{c|}{ Cultural characteristics } \\
\hline & & \multicolumn{1}{c|}{ Color } & \multicolumn{1}{c|}{ Texture } & \multicolumn{1}{c|}{ Hyphae } \\
\hline $\begin{array}{l}\text { Alternaia } \\
\text { alternata }\end{array}$ & PDA & $\begin{array}{l}\text { Light olive } \\
\text { green to brown }\end{array}$ & $\begin{array}{l}\text { Smooth or } \\
\text { verrucose }\end{array}$ & $\begin{array}{l}\text { Branched } \\
\text { hyphae }\end{array}$ \\
\hline
\end{tabular}

Table.5 Morphological characteristics of Alternaria alternate

\begin{tabular}{|c|c|c|c|c|c|}
\hline \multirow[t]{3}{*}{ Organisms } & \multicolumn{5}{|c|}{ Morphological characteristics } \\
\hline & \multicolumn{5}{|c|}{ Spore } \\
\hline & Type & Size & Shape & Septation & Arrangement \\
\hline $\begin{array}{l}\text { Alternaia } \\
\text { alternata }\end{array}$ & Chlamydospores & $\begin{array}{c}\text { Hyphae diameter: } \\
5.25-8.6 \mu \text {. } \\
\text { Conidia about } \\
25.5-46.75 \mu \times 15- \\
17.75 \mu\end{array}$ & $\begin{array}{l}\text { Club- shaped } \\
\text { spores single } \\
\text { or form chains }\end{array}$ & $\begin{array}{l}\text { Alternate } \\
\text { septate }\end{array}$ & $\begin{array}{c}\text { Conidia borne in } \\
\text { long chain }\end{array}$ \\
\hline
\end{tabular}

Table.6 Antagonistic activity of Trichoderma harzianum against Alternaria alternata under in-vitro

\begin{tabular}{|c|c|c|c|}
\hline \multicolumn{1}{|c|}{ Media } & $\begin{array}{c}\text { Growth of } \\
\text { Trichoderma } \\
\text { harzianum }\end{array}$ & $\begin{array}{c}\text { Growth of } \\
\text { Alternaria alternata }\end{array}$ & $\begin{array}{c}\text { Inhibition growth } \\
(\%)\end{array}$ \\
\hline Potato Dextrose Aar & $28(\mathrm{~mm})$ & $11(\mathrm{~mm})$ & $60.71 \%$ \\
\hline
\end{tabular}

Plate.1 Cultural characteristics of Trichoderma harzianum

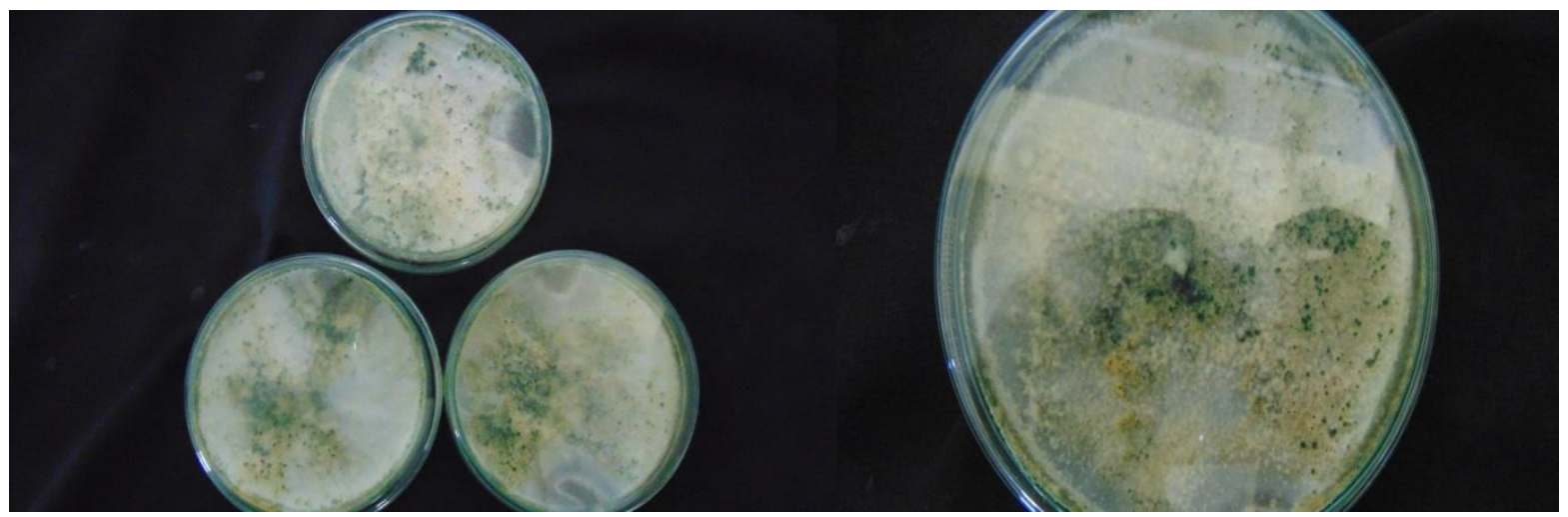


Plate.2 Morphological characteristics of Trichoderma harzianum (40X)
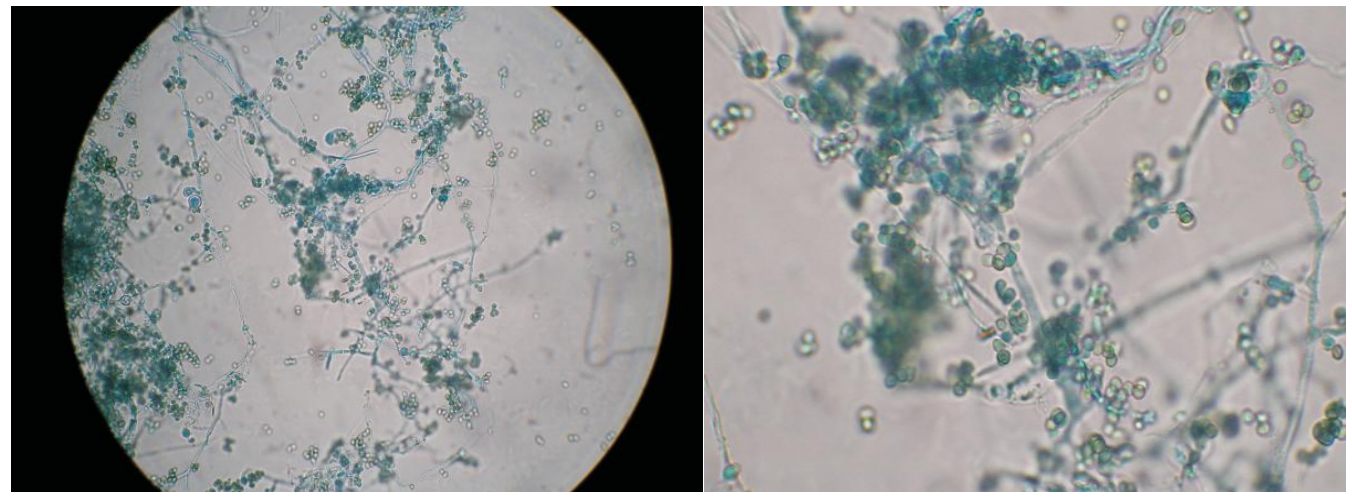

Plate.3 Amylase production test

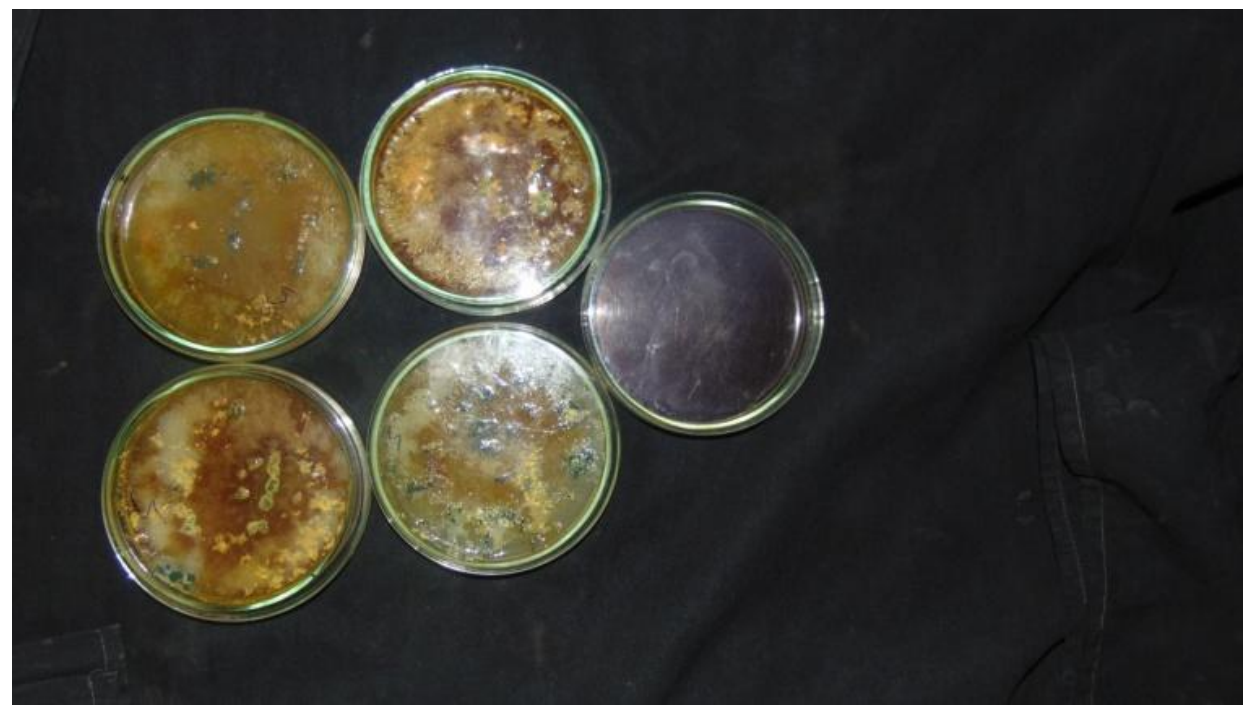

Plate.4 Cellulase production test

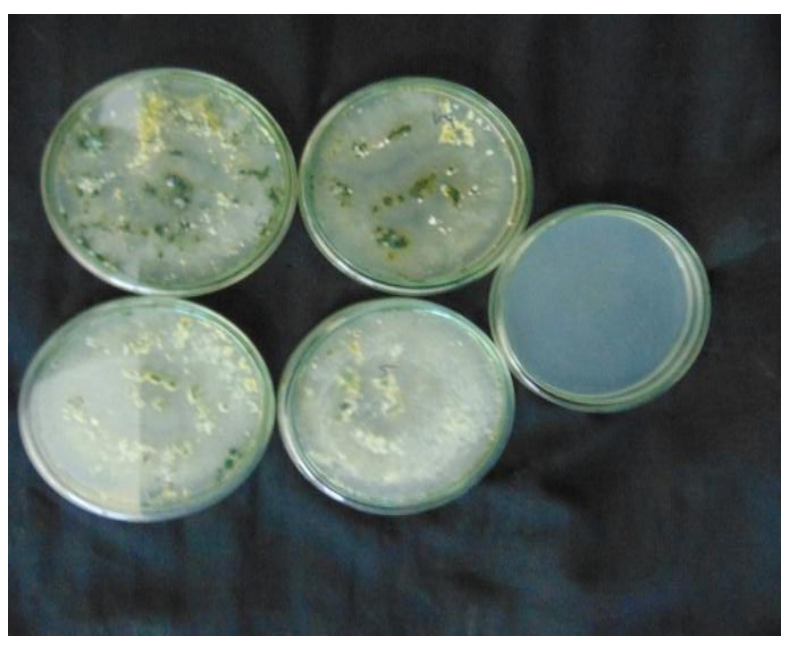


Plate.5 Cultural characteristics of Alternaria alternata
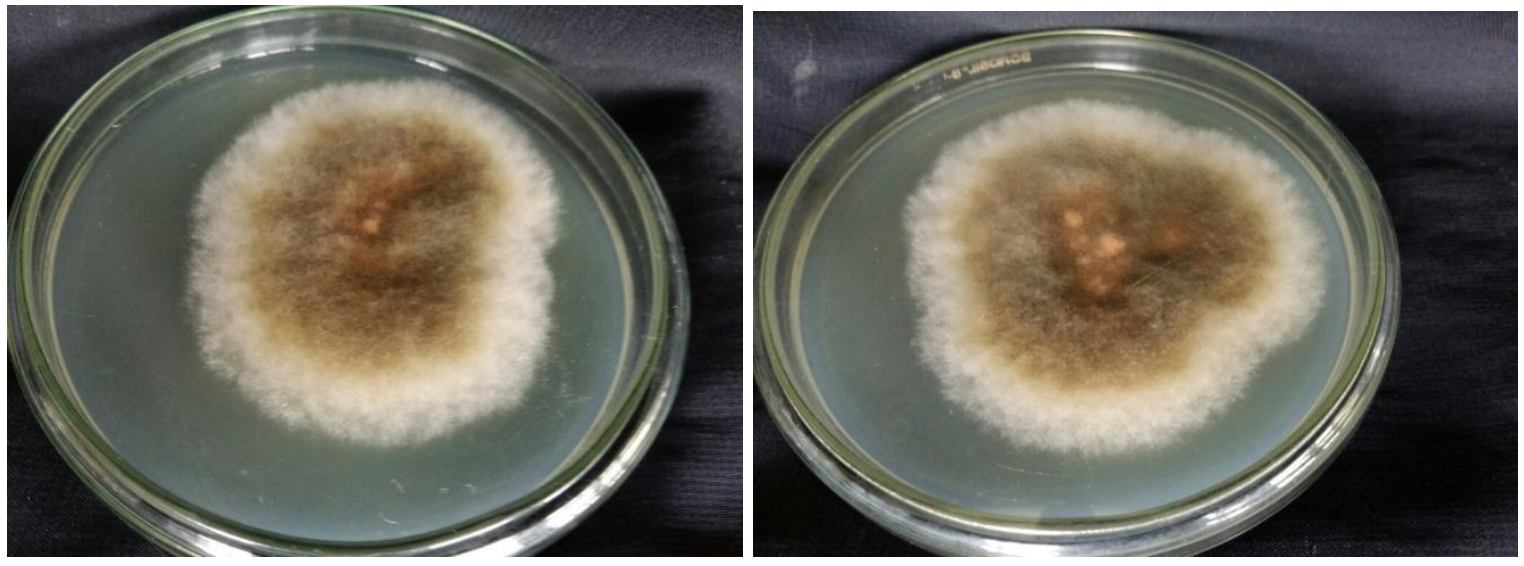

Plate.6 Morphological characteristics of Alternaria alternata (40X)

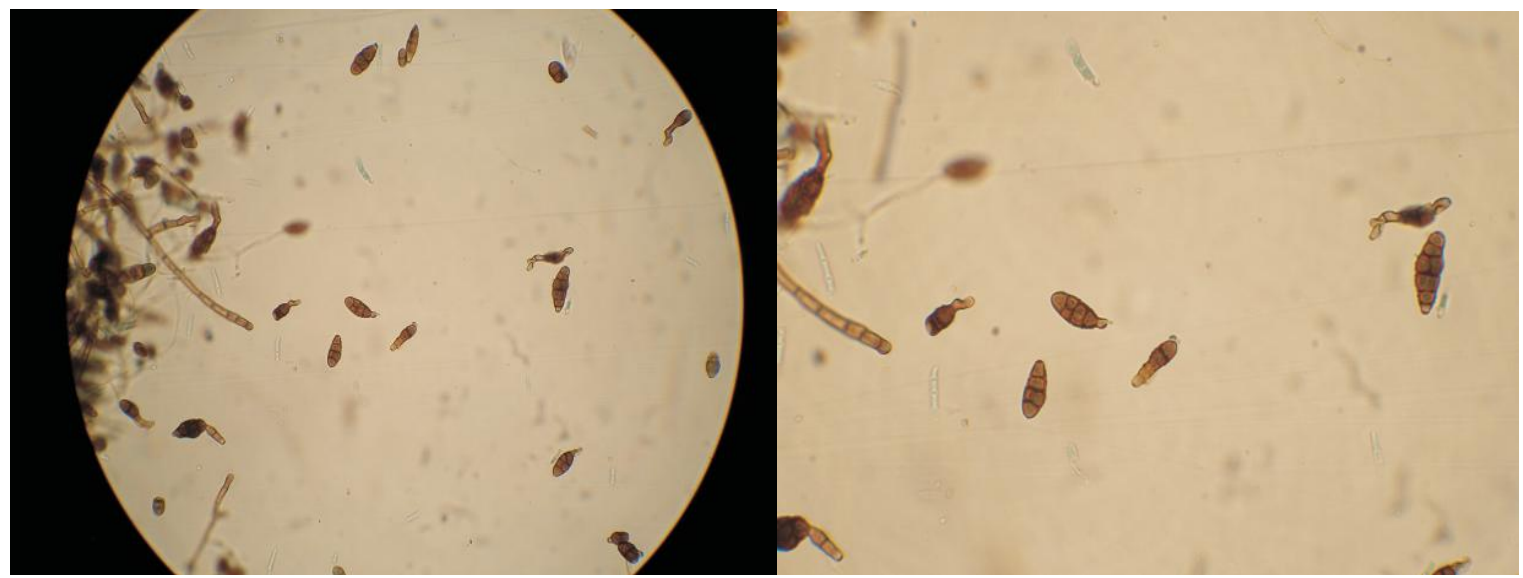

Plate.7 Antagonistic activity of Trichoderma harzianum against Alternaria alternata under in-vitro

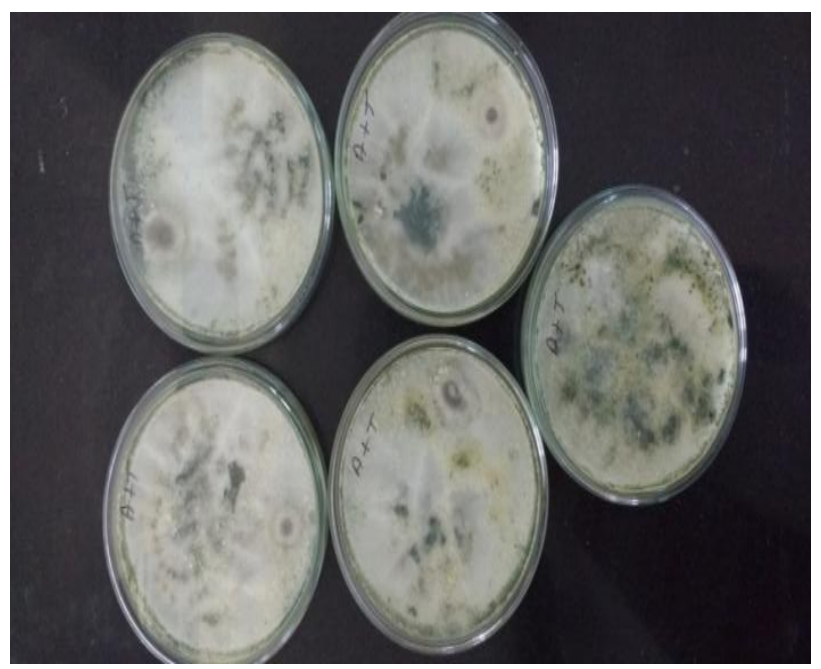


Antagonistic activity of Trichoderma harzianum against Alternaria alternata under in-vitro

The antagonistic activity of Trichoderma harzianum was screened in vitro against Alternaria alternata by dual culture plate technique on PDA media for 7days. The results revealed Trichoderma harzianum was shown inhibition of $60.71 \%$ over Alternaria alternata. Where Growth of Trichoderma harzianum and Alternaria alternata $28(\mathrm{~mm})$, $11(\mathrm{~mm})$ respectively. Similarly, Bardia and Rai (2007) showed antagonistic effect of Trichoderma viride and Trichoderma harzianum against Fusarium oxysporum f. sp. cuminis by $51.15 \%$ and $58.41 \%$ inhibition of mycelial growth respectively. Rehman et al., (2010) showed efficacy of Trichoderma viride and Trichoderma harzianum against Fusarium oxysporum f. sp. Ciceris by inhibition of mycelial growth $81 \%$ and $83.33 \%$ respectively. Cherkupally et al., (2017) evaluated the efficacy of Trichoderma viride and Trichoderma harzianum against Fusarium oxysporum f. sp. Melongenae by inhibition of mycelial growth $78.88 \%$ and $81.11 \%$ respectively.

The use of chemical fungicides to control plant diseases caused by pathogenic fungi which constrain the yield. However, overuse of these synthetic chemicals causes hazardous to both environment and health the alternative method for replacement of chemical fungicides has led to the use of biological control agents. Microorganisms that grow in the rhizosphere are ideal for use as biocontrol agents. The studies proved that Trichoderma harzianum have the potential to control Alternaria alternata under in vitro to the extent of $60.71 \%$ by dual culture plate technique. It may be therefore a promising ecofriendly bio controlling sources and cost effective for the safe agricultural practices as well as to farmers.

\section{Acknowledgement}

KVMS Chaitanya is thankful to the Department of Industrial Microbiology, Jacob Institute of Biotechnology and Bioengineering, SHUATS to providing lab facilities.

\section{References}

Aneja, K.R. 2003. Experiments in microbiology plant pathology and biotechnology $4^{\text {th }}$ edition New Age International Publisher, New Delhi India. Pp: 97-128.

Azevedo, D. Marco, D. Felix, C. 2000. Characterization of an amylase produce Trichoderma harzianum isolate with antagonistc activity against crinipellis periciosa, the causal agent of witches broom of cocoa. FEMS Microbiology. Lett., 188(2):171-175.

Gajera, H.P. and Vakharia, D.N. 2012. Production of lytic enzyme by Trichoderma isolates during in-vitro antagonism with Aspergillus niger, the causal agent of collar rot of pea nut. Brazilian Journal of Microbiology.

Kotle, S. J., 1985, Disease management strategies for rapeseed mustard crop in India. Agric. Rev., 6:81-88.

Kumar, R. and Gupta, P.P., 1994, Survival of Alternaria brassicae, Alternaria brassicicola and Alternaria alternata in the seed of mustard (B. juncea) at different temperatures and relative humidities. Ann. Biol. 10:55-58.

Nayyar, B. G., Akhund, S. and Akram, A., 2014, Management of Alternaria and its mycotoxins in crops. Scholarly Journal of Agricultural Science, 4(7):432-437.

Patni, C. S., Kolte, S. J. and Awasthi, R. P. 2005. Efficacy of botanicals against Alternariablight (Alternaria brassicae) of mustard. Indian Phytopath, 58 (4):426-430. 
Sheikh, R.A. and Agnihotri, J.P., 1972, Antifungal properties of some plant extracts. Ind. J. Mycol. Plant Pathol., 2:143-146.

Subash, N. Sundaram, M.M., Sasikumar, C. and Unnamalai, N. 2014. Mass cultivation of Trichoderma harzianum using agricultural waste as a substrate for the management of damping off disease and growth promotion in chilli plants (Capsicum annuum L.). International Journal of Pharmacy and Pharmaceutical Sciences.

Wukasch, R.T., 1985, Fungal Disease of Cruciferous Crops. Department of Environmental Biology, Pp. 252.

\section{How to cite this article:}

Chaitanya, K.V.M.S., Harison Masih and Pakkala Abhiram. 2018. Isolation of Trichoderma harzianum and Evaluation of Antagonistic Potential against Alternaria alternata. Int.J.Curr.Microbiol.App.Sci. 7(10): 2910-2918. doi: https://doi.org/10.20546/ijcmas.2018.710.338 